\section{Testicular expression of NGF, TrkA and p75 during seasonal spermatogenesis of the wild ground squirrel (Citellus dauricus Brandt)}

\author{
H. Zhang, Y. Wang, J. Zhan, L. Wang, \\ Q. Li, X. Sheng, Y. Han, Z. Yuan, Q. Weng \\ College of Biological Science and \\ Technology, Beijing Forestry University, \\ China
}

\begin{abstract}
The nerve growth factor (NGF) not only has an essential effect on the nervous system, but also plays an important role in a variety of nonneuronal systems, such as the reproductive system. The aim of this study was to compare the quality and quantity in expression of NGF and its receptors (TrkA and p75) in testes of the wild ground squirrel during the breeding and nonbreeding seasons. Immunolocalization for NGF was detected mainly in Leydig cells and Sertoli cells in testes of the breeding and nonbreeding seasons. The immunoreactivity of TrkA was highest in the elongated spermatids, whereas p75 in spermatogonia and spermatocytes in testes of the breeding season. In the nonbreeding season testes, TrkA showed positive immunostainings in Leydig cells, spermatogonia and primary spermatocytes, while p75 showed positive signals in spermatogonia and primary spermatocytes. Consistent with the immunohistochemical results, the mean mRNA and protein level of NGF and TrkA were higher in the testes of the breeding season than in non-breeding season, and then decreased to a relatively low level in the nonbreeding season. In addition, the concentration of plasma gonadotropins and testosterone were assayed by radioimmunoassay (RIA), and the results showed a significant difference between the breeding and nonbreeding seasons with higher concentrations in breeding season. In conclusion, these results of this study provide the first evidence on the potential involvement of NGF and its receptor, TrkA and p75 in the seasonal spermatogenesis and testicular function change of the wild ground squirrel.
\end{abstract}

\section{Introduction}

The nerve growth factor (NGF) is one kind of neurotrophins (NTs), which are mainly involved in the survival and development of discrete neuronal populations in the central and peripheral nervous system. ${ }^{1}$ The biological function of NGF requires two receptors p75 and TrkA to participate in. These two receptors have many specialties in different aspects. P75 is the low affinity receptor for NGF, which belongs to the tumor necrosis factor receptor superfamily. ${ }^{2}$ TrkA is the high affinity receptor for NGF, which belongs to the tyrosine protein kinase receptor family. ${ }^{3}$ Accumulating studies to date have suggested that the function of NGF is not only limited to the nervous system, but also extended to the non-nervous systems, including the male and female reproductive systems. ${ }^{4-6}$ In recent years, the studies of NGF and its receptors in reproductive system largely focus on the immunolocalization and expression of NGF system in reproductive organs, ${ }^{7,8}$ the functional role of NGF system in the follicular development ${ }^{9,10}$ and in spermatogenesis. $^{11-12}$ The studied species range from experimental models, such as rat, ${ }^{7,8,11}$ mouse ${ }^{12}$ and golden hamster, ${ }^{13,14}$ to primate $^{15}$ and human. ${ }^{16,17}$ Our previous results indicated that NGF and its receptors may be involved in the regulation of seasonal changes in the ovarian and uterine functions of wild female ground squirrels. ${ }^{18-20}$ However so far, whether NGF and its receptors also are present or not in the testes of wild rodents and their possible roles in seasonal spermatogenesis remain utterly unknown.

Reproductive strategies of seasonal breeders are adapted to annual changes of the environment, which minimize the animals' energetic efforts for reproduction. The wild ground squirrel (Citellus dauricus Brandt) is a typical seasonal breeder, with a short breeding season lasting from April to May and a long period of sexual dormancy from June to the following March. ${ }^{21,22}$ With this model, our laboratory has recently explored the coordinated roles of steroid hormones and local growth factors in the seasonal regulation of the functions of the reproductive organs, such as testis, epididymis, ovary and uterus. ${ }^{18-21,23-30}$ Yet, there are still many limitations in the understanding of the basic mechanisms underlying seasonal changes in spermatogenesis and testicular activity. Thus, the aim of the present study was to determine the regulated expression of NGF and its receptors in testes during the breeding and nonbreeding seasons, and to know the primary role of NGF in seasonal spermatogenesis in the wild ground squirrel.

\section{Materials and Methods}

\section{Animals and sample collection}

Thirty-eight wild male ground squirrels (23 in breeding season and 15 in non-breeding season), which were thought to be adult based
Correspondence: Dr. Qiang Weng, Laboratory of Animal Physiology, College of Biological Science and Technology, Beijing Forestry University, Beijing 100083, China.

Tel.Fax: +86.10.6233-6399.

E-mail: qiangweng@bjfu.edu.cn

Key words: NGF; p75; seasonal spermatogenesis; TrkA; wild ground squirrel.

Conflict of interest: the authors declare no conflict of interest.

Contributions: HZ, YW, JZ, LW, experiments performing, data analysis, manuscript drafting; $\mathrm{HZ}$, $\mathrm{QL}, \mathrm{XS}$, assisting in sample collection and all experiments, and in manuscript revision; $\mathrm{YH}, \mathrm{ZY}$, $\mathrm{QW}$, study design and supervision, and manuscript revision. All authors read and approved the final version.

Funding: this study was supported by a Grant-inAid from the Program for National Natural Science Foundation of China (NSFC, No. J1103516; No. J1310005) and Beijing Natural Science Foundation (8142029).

Received for publication: 14 April 2015.

Accepted for publication: 24 June 2015.

This work is licensed under a Creative Commons Attribution NonCommercial 3.0 License (CC BYNC 3.0).

() Copyright H. Zhang et al., 2015

Licensee PAGEPress, Italy

European Journal of Histochemistry 2015; 59:2522 doi:10.4081/ejh.2015.2522

on their body weights (242 412 g), were captured from April to September of 2011 in Hebei Province, China. The animals were decapitated after anesthesia using diethyl ether. Plasma samples were immediately collected and stored at $-20^{\circ} \mathrm{C}$. The testes were excised from each body after necropsy. Each obtained testis was cut into 2 portions: one portion was fixed in $4 \%$ paraformaldehyde in $0.05 \mathrm{M}$ PBS, pH 7.4 for immunohistochemical staining, and the second portion was immediately stored at $-80^{\circ} \mathrm{C}$ until used for Western blot detection and reverse transcription PCR. All the procedures on animals were carried out in accordance with the Policy on the Care and Use of Animals by the Ethical Committee, Beijing Forestry University and approved by the Department of Agriculture of Hebei province, PR China (JNZF11/2007).

\section{Antibodies}

Rabbit polyclonal primary antibodies against NGF $(0.4 \mu \mathrm{g} / \mathrm{mL}, \mathrm{M}-20)$, TrkA $(2 \mu \mathrm{g} / \mathrm{mL}, 763)$ and p75 (2 $\mu \mathrm{g} / \mathrm{mL}, \mathrm{H}-92)$ (Santa Cruz Biotechnology, Santa Cruz, CA, USA) were used for the immunohistochemistry and 
Western blot. These three antibodies were used at dilutions of 1:200 in PBS/0.5\% BSA and dilutions of 1:500 in TBS/0.1\% Tween20 for immunohistochemistry and Western blot, respectively. The specificity of these antibodies in the wild ground squirrel was confirmed and described previously. ${ }^{18-20}$

\section{Immunohistochemistry}

Five testes samples in each season were used for immunohistochemistry detection. The paraffin sections of testes were cut and incubated with $10 \%$ normal goat serum to reduce background staining caused by the secondary antibody. The sections were then incubated with polyclonal primary antibodies against NGF, TrkA or p75 for $12 \mathrm{~h}$ at room temperature. Thereafter, the sections were incubated with the secondary antibody goat anti-rabbit $\lg \mathrm{G}$ conjugated with biotin and peroxidase with avidin, using a rabbit ExtrAvidin staining kit (Sigma-Aldrich, St. Louis, M0, USA), followed by visualization with $30 \mathrm{mg}$ 3,3-diaminobenzidine (Wako, Tokyo, Japan) solution in $150 \mathrm{ml}$ of $0.05 \mathrm{~mol}$ Tris-HCl buffer, pH 7.6, plus $30 \mu \mathrm{l}$ $\mathrm{H}_{2} \mathrm{O}_{2}$. Finally, the reacted sections were counterstained with hematoxylin solution (Merck, Tokyo, Japan). The antibodies were mixed with the excess relative antigens (NGF antigen: SRP3015, Sigma-Aldrich; TrkA antigen: ab116686, Abcam, Cambridge, MA, USA; p75 antigen: SRP2026, Sigma-Aldrich) according with the molecular ratio of antibody: antigen 1:10 and incubated in $4^{\circ} \mathrm{C}$ for overnight, which were used instead of first antibodies in the control sections.

\section{Western blot}

Five testes samples in each season were used for Western blot detection. Testicular tissue was weighed and diced into small pieces using a clean razor blade. Tissue was homogenized in a homogenizer containing $300 \mu \mathrm{L}$ of $10 \mathrm{mg} / \mathrm{mL}$ PMSF stock and incubated on ice for $30 \mathrm{~min}$, maintaining temperature at $4^{\circ} \mathrm{C}$ throughout all procedures. Homogenates were centrifuged at $12,000 \mathrm{x}$ g for $10 \mathrm{~min}$ at $4^{\circ} \mathrm{C}$. Protein extracts $(25 \mu \mathrm{g})$ were mixed with an equal volume of $2 \times$ Laemmli's sample buffer. Equal amounts of each sample were loaded and run on a $12 \%$ SDS-PAGE gel at $18 \mathrm{~V} / \mathrm{cm}$ and transferred to nitrocellulose membranes using a wet transblotting apparatus (Bio-Rad Laboratories, Richmond, CA, USA). The membranes were blocked in 3\% BSA for $1 \mathrm{~h}$ at room temperature. Primary incubation of the membranes was carried out using rabbit anti-NGF antibody, rabbit anti-TrkA antibody and rabbit anti-p75 for $60 \mathrm{~min}$. Secondary incubation of the membrane was then carried out using a 1:1000 dilution of goat anti-rabbit IgG tagged with horseradish peroxidase for $60 \mathrm{~min}$. Finally, the membrane was colored with $25 \mathrm{mg}$ 3,3-diaminobenzidine (Wako, Tokyo, Japan) solution in $25 \mathrm{ml}$ TBS-T buffer $(0.02 \mathrm{M}$ Tris, $0.137 \mathrm{M} \mathrm{NaCl}$, and $0.1 \%$ Tween-20, pH 7.6) plus $3 \mu \mathrm{H}_{2} \mathrm{O}_{2}$. Preabsorptions of the antibodies were performed with an excess of relative antigens (NGF antigen: SRP3015, Sigma-Aldrich; TrkA antigen: ab116686, Abcam; p75 antigen: SRP2026, Sigma-Aldrich) according with the ratio of $1: 10$ as antibody:antigen in $4^{\circ} \mathrm{C}$ overnight and the preabsorbed antibodies in place of the primary antibodies were applied for the negative control. The intensities of the bands were quantified using Quantity One software (ver. 4.5, Bio-Rad Laboratories) and expression ratios were calculated.

\section{RNA isolation}

Total RNA was isolated from testicular tissues of wild ground squirrels (five samples for each season) using Trizol $^{\circledR}$ Reagent (Invitrogen, Carlsbad, CA, USA). Approximately $0.1 \mathrm{~g}$ of testicular tissues were thawed and immediately homogenized in $1 \mathrm{~mL}$ of Trizol Reagent. The homogenate was incubated for $5 \mathrm{~min}$ at room temperature to allow the complete dissociation of nucleoprotein complexes. After the addition of $0.2 \mathrm{ml}$ of chloroform, the mixture was vigorously shaken for 15 $s$ at room temperature and centrifuged at $12,000 \mathrm{x} \mathrm{g}$ for $15 \mathrm{~min}$ at $4^{\circ} \mathrm{C}$. The aqueous phase was then transferred to a fresh tube and an equal volume of isopropanol was added. Then the sample was kept for $10 \mathrm{~min}$ at room temperature. RNA was precipitated by centrifugation at $12,000 \mathrm{x}$ g for $10 \mathrm{~min}$ at $4{ }^{\circ} \mathrm{C}$. The RNA pellet was washed twice with $70 \%$ ethanol and dissolved in $50 \mu \mathrm{L}$ of diethylprocarbonatetreated water. The integrity of RNA was tested by gel electrophoresis and its concentration was measured with spectrophotometer.

\section{RT-PCR}

The first-strand cDNA from total RNA was synthesized using StarScript II Reverse Transcriptase and Oligo (dT) $)_{18}$ by TIANScript RT Kit (Tiangen, Beijing, China). The $20 \mu \mathrm{L}$ of reaction mixture contained $3 \mu \mathrm{L}$ of total RNA, $1 \mu \mathrm{L}$ of Oligo (dT) ${ }_{18}, 1 \mu \mathrm{L}$ of $10 \mathrm{mM}$ deoxyribonucleoside triphosphate (dNTP), $4 \mu \mathrm{L}$ of $250 \mathrm{Mm}$ Tris-HCl (pH 8.3), $375 \mathrm{mM} \mathrm{KCl}$ and 15 $\mathrm{mM} \mathrm{MgCl} 2,2 \mu \mathrm{L}$ of $0.1 \mathrm{M}$ dithiothreitol, $0.5 \mu \mathrm{L}$ of RNase Inhibitor and $200 \mathrm{U}$ of StarScript II enzyme. The $25 \mu \mathrm{L}$ of reaction mixture con- tained $2 \mu \mathrm{L}$ of first-strand cDNA, $0.5 \mu \mathrm{M}$ each primer, $1.5 \mathrm{mM} \mathrm{MgCl}_{2}, 0.2 \mathrm{mM}$ dNTP, $20 \mathrm{mM}$ Tris-HCl (pH 8.4) and 2.5 U of Taq polymerase (Tiangen). The amplification was under the following condition: $94^{\circ} \mathrm{C}$ for $3 \mathrm{~min}$ for the initial denaturation of the RNA/cDNA hybrid, 35 cycles of $94^{\circ} \mathrm{C}$ for $30 \mathrm{sec}, 51^{\circ} \mathrm{C}$ for $30 \mathrm{sec}$ and $72^{\circ} \mathrm{C}$ for $1 \mathrm{~min}$ with a final extension of $10 \mathrm{~min}$ at $72^{\circ} \mathrm{C}$. The first-strand cDNA was used for PCR amplification with the following primers as described by Li et al. ${ }^{18}$ (Table 1). The primer set was intron spanning. The PCR product was electrophoresed in the $1 \%$ agarose gel and individual bands were visualized by ethidium bromide (EB) staining. DEPC treated water was used instead of cDNA as negative control. The housekeeping gene, $R p L 7$, was selected as the endogenous control. The intensities of the bands were quantified using Quantity One software (ver. 4.5, Bio-Rad Laboratories) and expression ratios were calculated.

\section{Hormone assay}

Thirty-eight plasma samples were used for hormone assay. Plasma concentrations of testosterone (T) were determined by an RIA kit (Kit 02010304024; China Diagnostics Medical Corporation, Beijing, China) that was designed for the detection of rat hormones. Plasma samples of the wild ground squirrels were sent to the Beijing North Institute of Biological Technology for the detection of T. The intra-assay variation and the inter-assay variation were less than $10.3 \%$ and $15.4 \%$ for $\mathrm{T}$, respectively. The detection limit of sensitivity was $0.1 \mathrm{pg} / \mathrm{mL}$ for $\mathrm{T}$ and the detection limit of $\mathrm{T}$ is $0.25 \mathrm{pg}$. Plasma concentrations of folliclestimulating hormone (FSH) and luteinizing hormone (LH) were measured by double-antibody RIA systems using a rabbit antiserum against human FSH (\#6; provided by NIDDK NIH, Bethesda, MD, USA) and a rabbit antiserum against ovine LH (YM \#18; provided by Dr Y. Mori, Laboratory of Veterinary Ethology, University of Tokyo, Japan). The antisera used for LH and FSH were anti-rat LH-S-10 and antirat FSH-S-11, respectively. Iodinated preparations for LH and FSH were rat LH-I-7 and rat FSH-I-7, respectively. The standard for LH and FSH were rat LH-RP-2 and FSH-RP-2, respectively. The detection limit of LH and FSH are $0.003 \mathrm{ng} / \mathrm{mL}$ and $0.009 \mathrm{ng} / \mathrm{mL}$, respectively. The intra- and inter-assay coefficients of variation

Table 1. Oligonucleotide primer sequences for PCR amplifications.

\begin{tabular}{lll} 
Primer & \multicolumn{1}{c}{ Sense } & \multicolumn{1}{c}{ Antisense } \\
NGF & TCCACCCACCCAGTCTTC & GCTCGGCACTTGGTCTCA \\
TrkA & TCGGACCATGCTGCCCATCC & AGGCGTTGCTGCGGTTCTCG \\
\hline p75 & GGAGGACACGAGTCCTGAGC & CAGTGGAGAGTGCTGCAAAG \\
RpL 7 & TCAATGGAGTAAGCCCAAAG & CAAGAGACCGAGC198AATCAAG \\
\hline
\end{tabular}


were $8.8 \%$ and $13.1 \%$ for $\mathrm{LH}$ and $9.2 \%$ and $13.1 \%$ for FSH, respectively.

\section{Statistical analysis}

Mean values $( \pm \mathrm{SD})$ were calculated and analyzed using one-way ANOVA. Duncan's multiple range test was used for detection of significant differences using the SPSS computer package. Differences were determined to be statistically significant when $\mathrm{P}<0.05$.

\section{Results}

\section{Variations in testicular histology and spermatogenesis}

The testes of the breeding and nonbreeding seasons were observed morphologically and histologically (Figure 1). In line with our previous reports, both the testicular weight and volume were markedly higher in the breeding season than those in the nonbreeding season (Figure $1 \mathrm{a}, \mathrm{b} ; \mathrm{P}<0.01$ ). All types of spermatogenic cells including spermatozoa were found in the breeding season (Figure 1c), whereas spermatogonia and primary spermatocytes were present in seminiferous tubules in the nonbreeding season (Figure 1d). Based on the HE staining of the serial sections, we also quantified the numbers of different levels of spermatogenic cells (Figure 1 e,f).

\section{Testicular immunoreactivity of NGF, TrkA and p75 changes during the breading and nonbreeding \\ seasons}

Immunohistochemical staining for NGF and its receptors TrkA and p75 in the testes during the breeding and nonbreeding seasons are shown in Figure 2. Marked changes in immunolocalization of NGF and its receptors TrkA and p75 were observed between the two different reproductive seasons. In the breeding season, the strong immunoreactivity for NGF was found in Leydig cells and Sertoli cells (Figure 2a). Positive staining was also observed in the nonbreeding season (Figure $2 \mathrm{~g}$ ). Regarding the receptors, TrkA was mainly localized in elongated spermatids (Figure 2b) and the positive signal of p75 was detected in spermatogonia and spermatocytes in the breeding season testis (Figure 2c). While in the nonbreeding season testis, TrkA showed faintly positive immunostaining in Leydig cells, spermatogonia and primary spermatocytes (Figure 2h), and p75 showed positive immunostaining in spermatogonia and primary spermatocytes (Figure 2i). No positive signals were present in the testicular sections of breeding and nonbreeding seasons treated
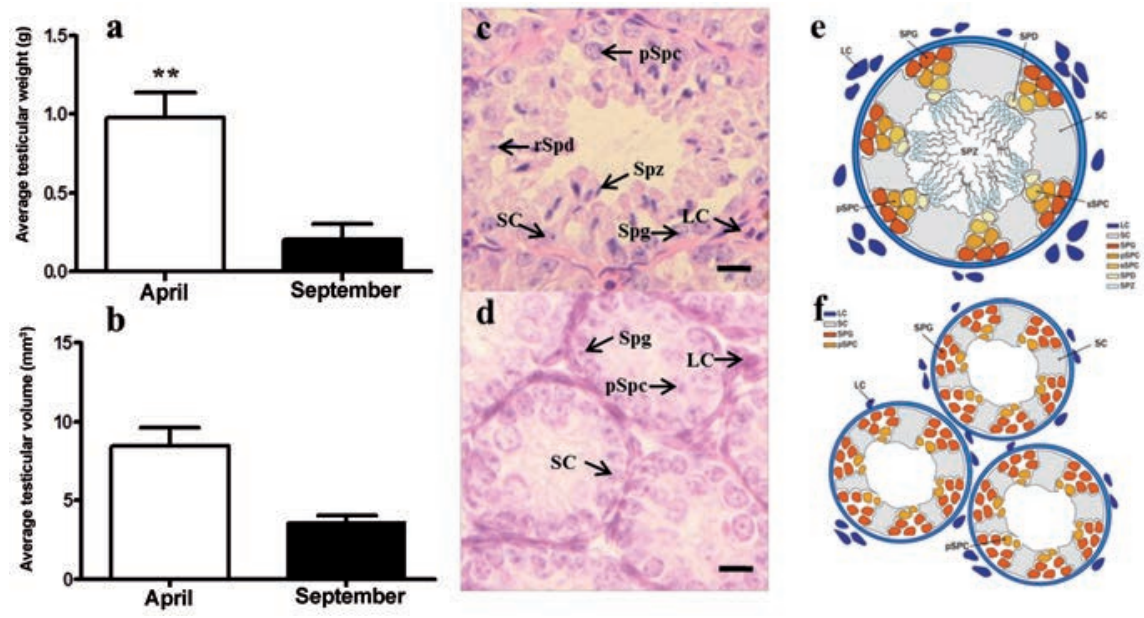

Figure 1. Morphological and histological features of testicular tissues of the wild ground squirrel during the breeding and nonbreeding periods. Marked seasonal differences were observed in testicular weight (a) and volume (b). Subsequently, HE staining was performed for the testes of the breeding (c) and nonbreeding season (d), and the sketch of spermatogenesis during the two periods were manually draw according to the histological results (e, f). LC, Leydig cell; SC, Sertoli cell; Spg, spermatogonia; pSpc, primary spermatocytes; rSpd, round spermatids; $S p z$, spermatozoon. ${ }^{* *} P<0.01$. Scale bars: $40 \mu \mathrm{m}$.

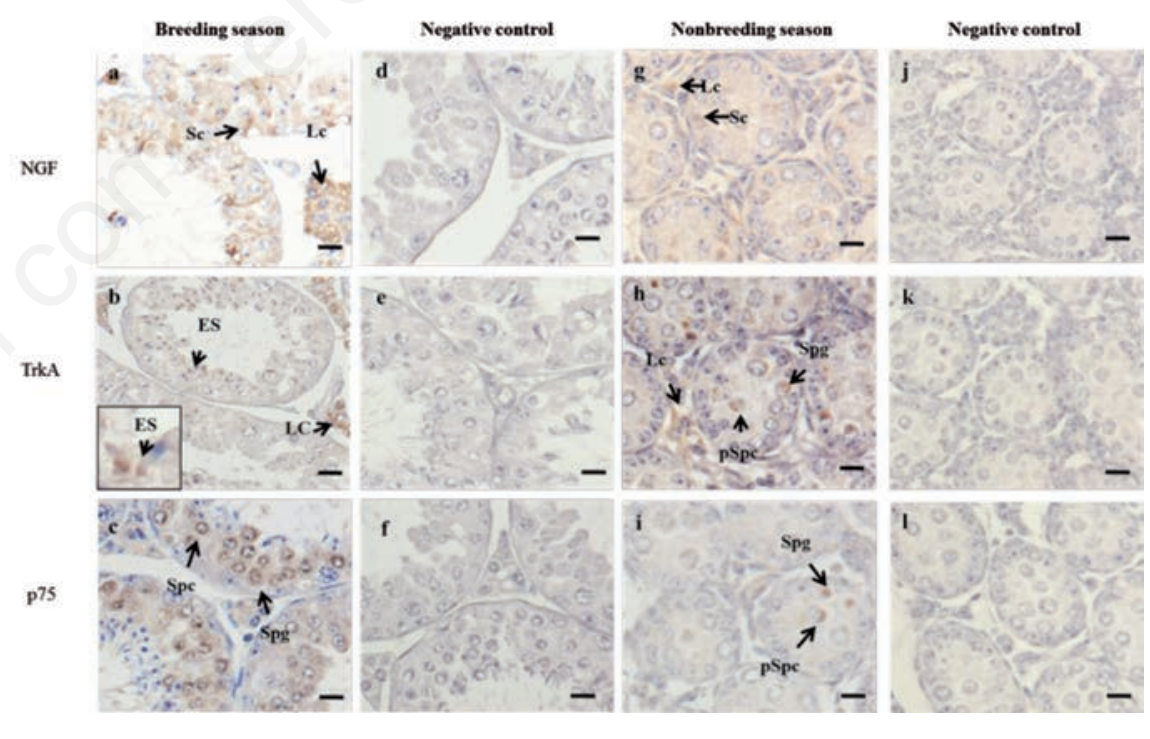

Figure 2. Immunohistochemistry for the NGF and its receptors TrkA and p75was executed in the testes during the breeding and nonbreeding seasons. Immunolocalization for NGF was found mainly in Leydig cells and Sertoli cells in breeding season (a), and no positive staining was observed in nonbreeding season (g). TrkA was mainly immunolocalized in elongated spermatids (b), and p75 was expressed in spermatogonia and spermatocytes in the breeding season (c). In the nonbreeding season, TrkA showed positive immunostaining in Leydig cells, spermatogonia and primary spermatocytes (h) and p75 showed positive immunostaining in spermatogonia and primary spermatocytes (i). No positive signal was present in the testicular sections of breeding and nonbreeding seasons, which were treated with respective preabsorbed primary antibodies $(d-f, j-l)$. The arrows in each panel indicated the position of positive staining. Lc, Leydig cells; Sc, Sertoli cells; Spg, spermatogonia; Spc, spermatocytes; pSpc, primary spermatocytes; ES, elongated spermatids. Scale bars: $40 \mu \mathrm{m}$. 
with preabsorbed primary antibodies (Figure 2 d-f, j-l).

\section{Changes in testicular protein and mRNA expressions of NGF, TrkA and p75 during the breading and nonbreeding seasons}

The protein and mRNA expression levels of NGF, TrkA and p75 using Western blot and RTPCR, and representative bands were shown in Figure 3 . The intensity of each band was normalized to the level of $\beta$-actin and RpL7, used as the endogenous control, for Western and RT-PCR detections, respectively. Both the protein and mRNA expression levels of NGF ligand and its receptors were significantly higher in the breeding season when compared to the nonbreeding season, basically inconsistent with the immunohistochemical results (Figure 3 a-f; $\mathrm{P}<0.01$ ). To further confirm the nature of the RT-PCR signals, cDNA fragments of NGF, TrkA and p75 in testicular tissues were sequenced and compared to the corresponding fragments in mouse, rat, bovine, and human. The 176-bp NGF cDNA nucleotide sequence identity was $92.11 \%, 90.20 \%, 81.70 \%$ and $86.18 \%$, respectively; the 261-bp TrkA cDNA nucleotide sequence identity was $94.32 \%$, $90.83 \%, 84.72 \%$ and $83.41 \%$, respectively; the 295-bp p75 cDNA nucleotide sequence identity was $94.42 \%, 88.10 \%, 84.01 \%$ and $83.64 \%$, respectively; the 207-bp Actb cDNA nucleotide sequence identity was $94.55 \%, 84.65 \%, 74.23 \%$ and $76.87 \%$, respectively (Table 2 ), which not only confirmed the specificity of RT-PCR primers but also suggested high affinities of NGF, TrkA and p75 genes among the wild ground squirrel and the species compared.

\section{Plasma concentration of $\mathrm{LH}, \mathrm{FSH}$ and testosterone}

The profiles of plasma LH, FSH and T are shown in Figure 4. Plasma LH, FSH and T concentrations were all remarkably higher in the breeding season as compared to the nonbreeding period (Figure 4 a-c; $\mathrm{P}<0.01$ ).

\section{Discussion}

To our knowledge, this is the first study to investigate the expression pattern of NGF system in the testes of a wild rodent, which shows that the expression of NGF is correlated with the changes of plasma LH, FSH and T concentration during the breeding and nonbreeding seasons. These findings suggest that NGF and its receptors TrkA and p75 may be involved in the regulation of seasonal changes in spermatogenesis and testicular function of the wild ground squirrels.
Accumulating evidence has proved the presence and potential function of NGF and its receptors in the reproductive system, in addition to their well-known roles within the nervous system. ${ }^{6-14}$ In adult male rat, NGF was found in Leydig cells, primary spermatocytes in the testis, while TrkA was detected in elongated spermatids and p75 in Sertoli cells, Leydig cells, primary spermatocytes and elongated spermatids. ${ }^{7}$ In Japanese monkey, Leydig cells, Sertoli cells and spermatogonia at various stages were positively stained for NGF, as well as for TrkA and $\mathrm{p} 75 .{ }^{15}$ In human testis, strong immunocytochemical expression of TrkA and p75 was present in Leydig cell, and Sertoli cells and some cellular elements of the seminifer-
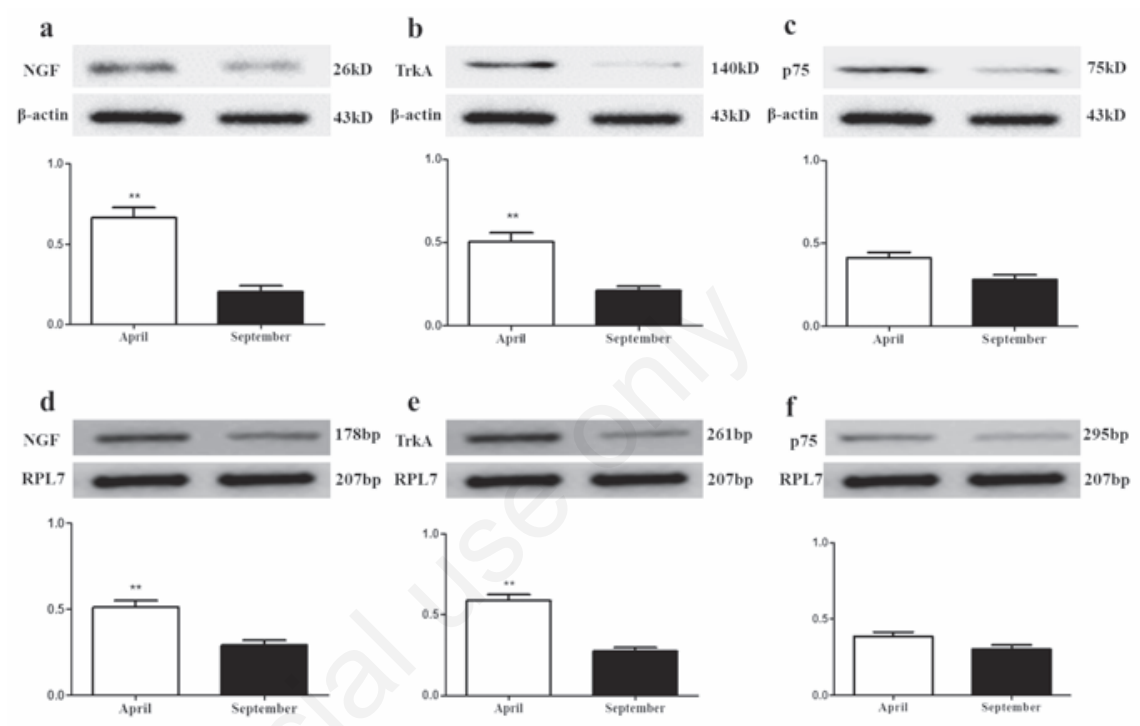

Figure 3. Western blot and RT-PCR detections of NGF (a,d), TrkA (b,e) and p75 (c,f) in testicular tissues of the wild ground squirrel during the breeding (April) and nonbreeding period (September), respectively. The Western blot results for NGF (a), TrkA (b) and p75 (c) are shown in the a, b and c panels, respectively; the RT-PCR results for NGF, TrkA and $\mathrm{p} 75$ are shown in the $d, e$ and $f$ panels, respectively. $\beta$-actin and ribosomal protein L7 blots shown were used as controls to correct for loading in each lane, respectively. The expression levels were determined by densitometric analysis. The bars represent the means \pm SD for five independent experiments. ${ }^{* *} \mathrm{P}<0.01$.
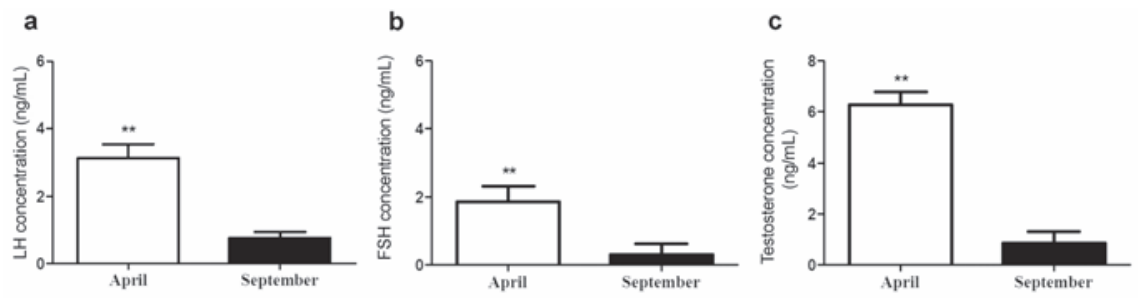

Figure 4. Plasma LH (a), FSH (b) and testosterone (c) levels in wild male ground squirrel during the breeding (April) and non-breeding perios (September). The bars represent the means \pm SD for five independent experiments. ${ }^{* *} \mathrm{P}<0.01$.

Table 2. Nucleotide sequence identity in ovarian tissues of wild ground squirrel in comparison with mouse, rat, bovine and human tissues (\%).

\begin{tabular}{lllll} 
& NGF & TrkA & p75 & RpL7 \\
Mouse & 92.11 & 94.32 & 94.42 & 94.55 \\
Rat & 90.20 & 90.83 & 88.10 & 84.65 \\
\hline Bovine & 81.70 & 84.72 & 84.01 & 74.23 \\
Human & 86.18 & 83.41 & 83.64 & 76.87 \\
\hline
\end{tabular}


ous epithelium. ${ }^{16}$ Even though the results seem species-specific, the presence of NGF system in the testis is indisputable. The present study, for the first time, reported the localizations of NGF and its receptors TrkA and p75 within the testis of wild ground squirrels as one of seasonal breeder. In general agreement with previous cases, we showed that NGF was mainly expressed in the Leydig cells and Sertoli cells, and the receptors were distributed in spermatogenic cells and/or somatic cell. On the other hand, in vitro studies using different cell lines have indicated that NGF acts as an autocrine/paracrine factor between somatic cells and spermatogenic cells. ${ }^{11,31}$ The in vivo study in rat further confirmed that NGF might be a meiotic growth factor acting in a paracrine manner through Sertoli cells, as the mRNA and protein of NGF and p75 were expressed at all stages of the cycle of rat seminiferous epithelium. ${ }^{32}$ Therefore, according with the results in the present study, NGF and its receptors TrkA and p75 may influence the testis function via autocrine/paracrine pathway in the wild ground squirrel.

As an autocrine/paracrine factor, the specific role of NGF system in the testis is still limitedly understood. In this study, considering the immunolocalizations of NGF and its receptors during the breeding season, which showed that NGF was expressed in Leydig cells and Sertoli cells, TrkA was expressed in elongated spermatids, and p75 was expressed in spermatogenic cells, it is reasonable to deduce that NGF synthesized by somatic cells might bind with its receptors expressed in germ cells to regulate germ cell meiotic differentiation during the active spermatogenesis of the wild ground squirrel. The similar hypothesis was supported by a previous study in rats. The results of in vivo and in vitro experiments in rats showed the $\beta$-NGF could affect the number of different stages of spermatogenic cells though the receptors expressed in germ cells. ${ }^{11}$ The different localizations of TrkA and p75 in testes of wild ground squirrels also indicated varied functions of TrkA and p75 in testes. Indeed, the different signaling pathways activated by TrkA and $\mathrm{p} 75$ have been shown in neurons and prostate cancer. ${ }^{33,34}$ Even though further evidence on the different signaling pathways in testes of wild ground squirrels need to be obtained, the present results suggest that NGF might influence the germ cell meiotic differentiation through its receptors expressed in different stages of spermatogenic cells in testes of wild ground squirrels during the breeding season. In breeding nonbreeding season, the immunolocalization of TrkA was changed in different stages of spermatogenesis, which is not specific in wild ground squirrels. In testes of newborn and adult rats, the immunolocalizations of TrkA were presented in different type of cells. ${ }^{35}$ The different immunolocalizations of $\mathrm{NGF}$ receptors in uterus of cyclic hamsters were found, which may be related to the change of estrogen and progesterone in uterus. ${ }^{36}$ Based on these data, we suspect that the different immunolocalization of TrkA in different seasons may be related to the hormone microenvironment in testes of wild ground squirrels. In addition, NGF secreted by Leydig cells passing through the blood-testis barrier is the prerequisite for NGF to react with its receptors in the germ cells. Although the exact mechanism for NGF passing though the blood-testis barrier is still unclear, many studies on the transportation through the blood-testis barrier suggested that many specific transporters, such as organic anion transporter 6 , vitamin $\mathrm{C}$ transporters and carnitine transporters, existed in the blood-testis barrier. ${ }^{37-39}$ These reports indicated that one possible way for NGF to pass through the blood-testis barrier was via binding the specific transporters. Another point which should be also concerned is that the Sertoli cell is highly dynamic and therefore the structure of the blood-testis barrier undergoes remodeling (opening and closing) during the process of spermatogenesis. ${ }^{40,41}$

In the present study, both Western blot and RT-PCR analysis showed that there were significant changes in the testicular expression of NGF and its receptors between breeding season and nonbreeding season. Meanwhile, the testicular activity of NGF system showed a positive correlation to the level of plasma $\mathrm{LH}$, FSH and testosterone concentration, which changed significantly between the breeding season and nonbreeding season with higher concentrations in breeding season. There data indicates that FSH/LH and/or testosterone might induce the expression of NGF in testes of wild ground squirrels. And indeed, the previous researches support this idea. In golden hamsters, hCG injection induced the expression of NGF, TrkA and p75 in ovarian interstitial cells, and LH antiserum injection will decrease the expression of NGF expression in ovarian interstitial cells. ${ }^{14,42}$ In the culture of sheep follicle shells, the production of NGF became apparent in the presence of both $\mathrm{LH}$ and FSH, and showed a clear dose-response behavior. $^{43}$ In the cultured bovine oviduct epithelial cells, the levels of NGF mRNA were greater in cells treated with exogenous FSH or LH than those in negative control cells. ${ }^{44}$ Considering these data, it can be speculated that FSH/LH could induce the expression of NGF in testes of wild ground squirrels. Furthermore, several studies have already suggested that testosterone could increase the expression of NGF. ${ }^{45,46}$ For instance, a testosterone treatment was able to increase NGF expression in rat brain ${ }^{45}$ or mouse submaxil- lary glands. ${ }^{46}$ Given this, it is reasonable to suggest that increased testosterone by $\mathrm{FSH} / \mathrm{LH}$ may also induce the expression of NGF in the wild ground squirrel testis. Our previous studies on testes suggested there were significant changes in testicular weight, size and spermatogenesis score between breeding season and nonbreeding season in testes of wild ground squirrels. ${ }^{21,23,24}$ Therefore, the present study suggests that there are coordinated roles of plasma LH, FSH and T and NGF in the seasonal reproduction of the wild ground squirrel.

Yet, the mechanism underlying the seasonal testicular morphology and function variation remains elusive. Our previous publication implied that correlated with changes in plasma LH, FSH and estradiol-17 $\beta$ concentrations, NGF system may be involved in the regulation of seasonal changes in the ovarian functions of wild female ground squirrels. ${ }^{20}$ The data from the present study successfully fills in the gap of neurotrophin expression in the testis of a seasonal breeder and suggested that NGF system might be actively involved in the seasonal changes in spermatogensis and testicular activity. As we recently found that spermatogensis and testicular function of the wild ground squirrel re-activated during, instead of after, winter hibernation, ${ }^{30}$ it will be interesting to further investigate if NGF system also plays a role in this particular process, when the activity of nervous system reaches the low level, for the future research.

\section{References}

1. Levi-Montalcini R. The nerve growth factor 35 years later. Science 1987;237:1154-62.

2. Johnson D, Lanahan A, Buck CR, Sehgal A, Morgan C, Mercer E, et al. Expression and structure of the human NGF receptor. Cell 1986;47:545-54.

3. Kaplan DR, Martin-Zanca D, Parada LF. Tyrosine phosphorylation and tyrosine kinase activity of the trk proto-oncogene product induced by NGF. Nature 1991;350: 158-60.

4. Snider WD. Functions of the neurotrophins during nervous system development: what the knockouts are teaching us. Cell 1994;77:627-38.

5. Russo MA, Giustizieri ML, Favale A, Fantini MC, Campagnolo L, Konda D, et al. Spatiotemporal patterns of expression of neurotrophins and neurotrophin receptors in mice suggest functional role in testicular and epididymal morphogenesis. Biol Reprod 1999;61:1123-32.

6. Dissen GA, Parrott JA, Skinner MK, Hill DF, Costa ME, Ojeda SR. Direct effects of nerve growth factor on thecal cells from 
antral ovarian follicles. Endocrinology 2000;141:4736-50.

7. Li C, Watanabe G, Weng Q, Jin W, Furuta C, Suzuki AK, et al. Expression of nerve growth factor (NGF), and its receptors TrkA and p75 in the reproductive organs of the adult male rat. Zoolog Sci 2005;22:933-7.

8. Squillacioti C, De Luca A, Paino S, Langella E, Mirabella N. Effects of castration on the expression of the NGF and TrkA in the vas deferens and accessory male genital glands of the rat. Eur J Histochem 2009;53:e29.

9. Dissen GA, Hiirshfield AN, Malamed S, Hill DF, Ojeda SR. Expression of neurotrophins and their receptors in the mammalian ovary is developmentally regulated: changes at the time of folliculogenesis. Endocrinology 1995;136:4681-92.

10. Ojeda SR, Romero C, Tapia V, Dissen GA. Neurotrophic and cell-cell dependent control of early follicular development. Mol Cell Endocrinol 2000;163:67-71.

11. Perrard MH, Vigier M, Damestoy A, Chapat C, Silandre D, Rudkin BB, et al. Beta-nerve growth factor participates in an auto/ paracrine pathway of regulation of the meiotic differentiation of rat spermatocytes. J Cell Physiol 2007;210:51-62.

12. Ayer-Lelievre C, Olson L, Ebendal T, Hallböök F, Persson H. Nerve growth factor mRNA and protein in the testis and epididymis of mouse and rat. Proc Natl Acad Sci USA 1988;85:2628-32.

13. Weng Q, Shi ZQ, Kawaguchi M, Watanabe G, Taya K. Expression of nerve growth factor and its receptors trkA and p75 and inhibin alpha-subunit in the ovarian interstitial cells of lactating golden hamsters. J Reprod Dev 2008;54:397-401.

14. Weng Q, Shi ZQ, Tukada J, Watanabe G, Taya K. Immunodetection of NGF, trkA, p75 and inhibin $\alpha$-subunit in interstitial cells of golden hamsters treated with hCG. J Reprod Dev 2009;55:622-8.

15. Jin W, Arai KY, Shimizu K, Kojima C, Itoh M, Watanabe G, et al. Cellular localization of NGF and its receptors trkA and p75LNGFR in male reproductive organs of the Japanese monkey, Macaca fuscata fuscata. Endocrine 2006;29:155-60.

16. Seidl K, Holstein AF. Evidence for the presence of nerve growth factor (NGF) and NGF receptors in human testis. Cell Tissue Res 1990;261:549-54.

17. MacGrogan D, Saint-Andre JP, Dicou E. Expression of nerve growth factor and nerve growth factor receptor genes in human tissues and in prostatic adenocarcinoma cell lines. J Neurochem 1992;59: 1381-91.

18. Li B, Sheng X, Song M, Zhang H, Weng J, Zhang M, et al. Expression of nerve growth factor and its receptors TrkA and p75 in the uterus of wild female ground squirrel (Citellus dauricus Brandt). Gen Comp Endocrinol 2012;176:62-9.

19. Li B, Sheng X, Bao L, Huang S, Li Q, Liu Y, et al. Seasonal changes in expression of nerve growth factor and its receptors TrkA and p75 in the ovary of wild ground squirrel (Citellus dauricus Brandt). J Ovarian Res 2014;7:3.

20. Bao L, Li Q, Liu Y, Li B, Sheng X, Han Y, et al. Immunolocalization of NGF and its receptors in ovarian surface epithelium of the wild ground squirrel during the breeding and nonbreeding seasons. Eur $\mathrm{J}$ Histochem 2014;58:2363.

21. Sheng X, Zhang H, Zhang W, Song M, Zhang M, Li B, et al. Seasonal changes in spermatogenesis and immunolocalization of inhibin/activin subunits in the wild male ground squirrel (Citellus dauricus Brandt). J Reprod Dev 2008;54:460-4.

22. Pudney J, Canick JA, Clifford NM, Knapp JB, Callard GV. Location of enzymes of androgen and estrogen biosynthesis in the testis of the ground squirrel. Biol Reprod 1985;33:971-80.

23. Zhang H, Sheng X, Hu X, Li X, Zhang M, Li $B$, et al. Seasonal changes in spermatogenesis and immunolocalization of cytochrome P450 17 $\alpha$-hydroxylase /c17-20 lyase and cytochrome P450 aromatase in wild male ground squirrel (Citellus dauricus Brandt). J Reprod Dev 2010;56:297-302.

24. Sheng X, Zhang H, Zhang M, Zhang W, Hu $\mathrm{X}$, Song $\mathrm{M}$, et al. Seasonal changes in immunoreactivity of activin signaling component proteins in wild ground squirrel testes. J Reprod Dev 2012;58:126-31.

25. Zhang M, Sheng X, Zhang H, Wang $Q$, Xu $M$, Weng $Q$, et al. Seasonal changes in morphology and immunoreactivity of PDGF-A and its receptor PDGFR- $\alpha$ in the epididymis of wild ground squirrels (Citellus dauricus Brandt). J Reprod Dev 2012;58:353-9.

26. Li X, Zhang H, Sheng X, Li B, Zhou J, Xu M, et al. Immunoreactivities of androgen receptor, estrogen receptors, p450arom, $\mathrm{p} 450 \mathrm{c} 17$ proteins in wild ground squirrels ovaries during the nonbreeding and breeding seasons. J Ovarian Res 2012;5:26-35.

27. Sheng X, Weng J, Zhang H, Li X, Zhang M, $\mathrm{Xu} \mathrm{M}$, et al. Immunohistochemical localization of inhibin/activin subunits in the wild ground squirrel (Citellus dauricus Brandt) ovary. J Reprod Dev 2012;58:531-6.

28. Weng J, Li B, Sheng X, Zhang H, Hu X, Zhou J, et al. Seasonal changes in immunoreactivity of vascular endothelial factor and its receptors VEGFR1 and VEGFR2 in the uterus of wild ground squirrels (Citellus dauricus Brandt). J Reprod
Dev 2012;58: 537-43.

29. Zhang M, Sheng X, Sun R, Li Q, Zhang H, Zhou J, et al. Seasonal changes in immunoreactivity of inhibin/activin subunits in the epididymis of wild ground squirrels (Citellus dauricus Brandt). J Reprod Dev 2013;59:302-7.

30. Li Q, Zhang F, Zhang S, Sheng X, Han Y, Yuan Z, et al. Seasonal expression of androgen receptor, aromatase, and estrogen receptor alpha and beta in the testis of the wild ground squirrel (Citellus dauricus Brandt). Eur J Histochem 2015;59:2462.

31. Vidal F, Lopez P, López-Fernández LA, Ranc F, Scimeca JC, Cuzin F, et al. Gene trap analysis of germ cell signaling to Sertoli cell: NGF-TrkA mediated induction of Fral and Fos by post-meiotic germ cells. J Cell Sci 2001;114:435-43.

32. Parvinen M, Pelto-Huikko M, Söder 0, Schultz R, Kaipia A, Mali P, et al. Expression of $\beta$-nerve growth factor and its receptor in rat seminiferous epithelium: specific function at the onset of meiosis. J Cell Biol 1992;117:629-41.

33. Mendell LM. Does NGF binding to p75 and trkA receptors activate independent signalling pathways to sensitize nociceptors? J Physiol 2002;544(Pt 2):333.

34. Arrighi N, Bodei S, Zani D, Simeone C, Cunico SC, Missale C, et al. Nerve growth factor signaling in prostate health and disease. Growth Factors 2010;28:191-201.

35. Levanti MB, Germanà A, Carlos $\mathrm{F}$ de, Ciriaco E, Vega JA, Germanà G. Effects of increased nerve growth factor plasma levels on the expression of TrkA and p75NTR in rat testicles. J Anat 2006;208:373-9.

36. Shi Z, Arai KY, Jin W, Weng Q, Watanabe G, Suzuki AK, et al. Expression of nerve growth factor and its receptors NTRK1 and TNFRSF1B is regulated by estrogen and progesterone in the uteri of golden hamsters. Biol Reprod 2006;74:850-6.

37. Schnabolk GW, Gupta B, Mulgaonkar A, Kulkarni M, Sweet DH. Organic anion transporter 6 (Slc22a20) specificity and Sertoli cell specific expression provide new insight to potential endogenous roles. J Pharmacol Exp Ther 2010;334:927-35.

38. Angulo C, Castro MA, Rivas CI, Segretain D, Maldonado R, Yanez AJ, et al. Molecular identification and functional characterization of the vitamin $\mathrm{C}$ transporters expressed by Sertoli cells. J Cell Physiol 2008;217:708-16.

39. Kobayashi D, Goto A, Maeda T, Nezu J, Tsuji A, Tamai I. OCTN2-mediated transport of carnitine in isolated Sertoli cells. Reproduction 2005;129:729-36.

40. Mital P, Hinton BT, Dufour JM. The bloodtestis and blood-epididymis barriers are more than just their tight junctions. Biol 
Reprod 2011;84:851-8.

41. Meng J, Holdcraft RW, Shima JE, Griswold MD, Braun RE. Androgens regulate the permeability of the blood-testis barrier. Proc Natl Acad Sci USA 2005;102:16696-700.

42. Mattioli M1, Barboni B, Gioia L, Lucidi P. Nerve growth factor production in sheep antral follicles. Domest Anim Endocrinol 1999;17:361-71.

43. Li C, Ma Y, Yi K, Wang C, Li W, Liu Z, et al. The interactions between nerve growth factor and gonadotrophins in bovine oviduct. Anim Reprod Sci 2014;149:117-23.

44. Shi Z, Jin W, Watanabe G, Suzuki AK, Takahashi S, Taya K. Expression of nerve growth factor (NGF), and its receptors trkA and p75 in ovaries of the cyclic golden hamster (Mesocricetus auratus) and the regulation of their production by luteinizing hormone. J Reprod Dev 2004;50:605-11.

45. Bimonte-Nelson HA, Singleton RS, Nelson ME, Eckman CB, Barber J, Scott TY, et al.
Testosterone, but not nonaromatizable dihydrotestosterone, improves working memory and alters nerve growth factor levels in aged male rats. Exp Neurol 2003;181: 301-12.

46. Black MA, Lefebvre FA, Pope L, Lefebvre YA, Walker P. Thyroid hormone and androgen regulation of nerve growth factor gene expression in the mouse submandibular gland. Mol Cell Endocrinol 1992;84:145-54. 